\title{
Access to health in city slum dwellers: The case of Sodom and Gomorrah in Accra, Ghana
}

\begin{tabular}{|c|c|}
\hline $\begin{array}{l}\text { Authors: } \\
\text { Frances E. Ou } \\
\text { Harry Tagbor } \\
\text { Mabel Afi Tog }\end{array}$ & $\begin{array}{l}\text { usu-Ansah }{ }^{1} \\
\text { be }^{3}\end{array}$ \\
\hline $\begin{array}{l}\text { Affiliations: } \\
{ }^{1} \text { Department } \\
\text { Sciences, Sch } \\
\text { Sciences, Kwa } \\
\text { University of } \\
\text { Technology, G }\end{array}$ & $\begin{array}{l}\text { of Behavioural } \\
\text { ool of Medical } \\
\text { me Nkrumah } \\
\text { science and } \\
\text { hana }\end{array}$ \\
\hline $\begin{array}{l}{ }^{2} \text { Department } \\
\text { Health, Schoo } \\
\text { Sciences, Kwa } \\
\text { University of } \\
\text { Technology, G }\end{array}$ & $\begin{array}{l}\text { of Community } \\
\text { I of Medical } \\
\text { me Nkrumah } \\
\text { science and } \\
\text { hana }\end{array}$ \\
\hline $\begin{array}{l}{ }^{3} \text { Military Hosk } \\
\text { Ghana }\end{array}$ & ital, Accra, \\
\hline $\begin{array}{l}\text { Correspondin } \\
\text { Frances Owus } \\
\text { feoansah@ya }\end{array}$ & $\begin{array}{l}\text { g author: } \\
\text { u-Ansah, } \\
\text { hoo.com }\end{array}$ \\
\hline $\begin{array}{l}\text { Dates: } \\
\text { Received: } 20 \\
\text { Accepted: } 08 \\
\text { Published: } 29\end{array}$ & $\begin{array}{l}\text { an. } 2015 \\
\text { Oct. } 2015 \\
\text { Mar. } 2016\end{array}$ \\
\hline $\begin{array}{l}\text { How to cite th } \\
\text { Owusu-Ansah } \\
\text { Togbe MA. Ac } \\
\text { in city slum dy } \\
\text { case of Sodon } \\
\text { in Accra, Ghar } \\
\text { Health Care F } \\
2016 ; 8(1), \text { a8 } \\
\text { doi.org/10.41 } \\
\text { v8i1.822 }\end{array}$ & $\begin{array}{l}\text { is article: } \\
\text { FE, Tagbor H, } \\
\text { cess to health } \\
\text { vellers: The } \\
\text { nand Gomorrah } \\
\text { רa. Afr J Prm } \\
\text { am Med. } \\
\text { 22. http://dx. } \\
02 / \text { phcfm. }\end{array}$ \\
\hline $\begin{array}{l}\text { Copyright: } \\
\text { ( 2016. The } \\
\text { Licensee: AOS } \\
\text { licensed unde } \\
\text { Commons Att } \\
\text { License. }\end{array}$ & $\begin{array}{l}\text { luthors. } \\
\text { IS. This work is } \\
\text { rthe Creative } \\
\text { ibution }\end{array}$ \\
\hline Read online: & \\
\hline 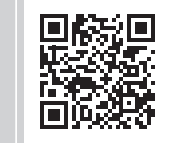 & $\begin{array}{l}\text { Scan this QR } \\
\text { code with your } \\
\text { smart phone or } \\
\text { mobile device } \\
\text { to read online. }\end{array}$ \\
\hline
\end{tabular}

Authors:

Harry Tagbor ${ }^{2}$

Mabel Afi Togbe

Affiliations:

'Department of Behavioural Sciences, Kwame Nkrumah University of Science and Technology, Ghan

Department of Community University of Science and chology, Ghan

${ }^{3}$ Military Hospital, Accra,

Corresponding author: Frances Owusu-Ansah

Dates:

Accepted: 08 Oct. 2015

How to cite this article: Owusu-Ansah FE, Tagbor H, Togbe MA. Access to health in city slum dwellers: The in Accra, Ghana. Afr J Prm Health Care Fam Med. doi.org/10.4102/phcfm.

Copyright:

(c) 2016. The Authors. Licensee: AOSIS. This work is licensed under the Creative Commons Attribution License.

mobile device
to read online
Background: Rapid rural-urban migration of people to cities is a reality around the globe that has increased city slum dwellers. Sodom and Gomorrah is a city slum located in the heart of Accra, Ghana. Like other slums, it lacks basic amenities necessary for dwellers' quality of life. This study describes residents' access to health and factors associated with the use of healthcare facilities.

Methods: Questionnaires were administered in systematically selected shacks across the entire slum. Data on demographic characteristics, existent health facilities and number of users, health-insured residents and knowledge of common diseases were collected.

Results: Majority of the residents were from the northern parts of Ghana, relative to the south and a few of them come from other parts of West Africa. Seventy-one percent of residents had never visited a health facility in the last 5 years. When necessary, they access health care from drug stores $(61.1 \%)$ or hospitals $(33.1 \%)$. Residents' age, educational status, income, health knowledge and membership of National Health Insurance Scheme were significantly $(p<0.05)$ associated with the use of healthcare facilities. Younger residents and those without National Health Insurance Scheme membership, formal education, no knowledge of common illnesses and regular income were significantly less likely to use a healthcare facility. For most residents, neither distance $(73.2 \%)$ nor transportation to health facilities was a problem $(74.1 \%)$.

Conclusion: Conditions of profound environmental hazards, overcrowding, poor-quality housing and lack of health care in Sodom and Gomorrah pose grave threats to the health of the inhabitants. Multisectoral interventions and resource mobilisation championed by the Ministry of Local Government and Rural Development are needed to alter the trend.

\section{Background}

A slum, according to the United Nations and UN-Habitat, is a run-down area of a city characterised by poor substandard structural quality of housing, insecure residential status, squalor, overcrowding and lack of basic amenities. ${ }^{1,2,3}$ Slums are usually inhabited by the very poor or socially disadvantaged groups, with a yearly increase in city slum dwellers in developing countries because of population growth and rural-urban migration. ${ }^{1,2,3,4}$ Poverty in the slums is reflected in the inadequate access to basic human needs such as clean water, nutrition, clothing, shelter, education and health care. ${ }^{5,6}$ Slum dwellers are caught up in a vicious cycle of economical and psychological poverty. Stack poverty makes it difficult for them to afford many essentials of life; they experience grave deprivation pushing them into a state of despondency. ${ }^{1,2,3}$

City slums may geographically be close to healthcare facilities, yet residents are deprived of access to needed health care resulting in negative economic and health consequences. ${ }^{7}$ The overcrowding and poor housing coupled with the dirt and squalor and lack of financial resources contribute to the presence and spread of varied infectious diseases in slums, affecting women and children mainly. ${ }^{1,2,3,8,9,10}$ Maternal mortality, high vulnerability to HIV infection, high unmet need for family planning and developmental challenges in children and adolescents are just a few of the many negative results of poor access to health in city slums. . $^{10,11,12,13,14,15}$

Improving living conditions and access to quality health care for all, particularly for slums dwellers, is central to development and speedy realization of the Millennium Development Goals (MDGs) in any country. Efforts towards achieving the first MDG goal, eradication of extreme poverty, through cross-cutting appears more urgent in slums where poverty is demonstrably present. ${ }^{1,6,8}$ Three of the MDGs - 4, 5, and 6 - specifically focus on health and seek to reduce infant and maternal mortality and combat diseases such as HIV and malaria, 
conditions which are unfortunately rampant in slums.,16 To be effective, interventions aimed at making lasting changes must be context-specific, empowering and evidencebased. It is in this regard that research in this area is essential if strategies are to produce the desired outcomes.

The purpose of the study was to examine health issues in Sodom and Gomorrah in Accra, Ghana, and factors that may be associated with accessing healthcare facilities in the last year. This study is timely in the light of the fact that even though a plethora of studies on slums exist, very few have looked at the situation in sub-Saharan Africa and studies on Ghana are practically nonexistent. Because slums around the globe share similar characteristics of poverty and deprivations in many spheres of life, including health care, , $, 4,8,10,11,14,16,17,18,19$ it is expected that findings from this study can provide insights into some of the health issues of other city slums within the country and sub-Saharan Africa for appropriate and targeted interventions.

\section{Methods}

\section{Study area and population}

The survey was conducted in Sodom and Gomorrah, a slum within Accra city, near the Korle Bu Teaching Hospital (KBTH). It stretches across 146 hectares and houses an estimated 25000 to 40000 residents. Residents are ethnically diverse, mostly poor, barely educated and generally unemployed or engaged in odd, nonpermanent jobs. Sodom and Gomorrah is characterised by poor housing, dirt and squalor, overcrowding and inadequate access to safe and clean water, sanitation and other infrastructure. It is one of the world's digital dumping grounds, where millions of electronic waste products from the West are crudely processed each year. ${ }^{20}$ The study population consisted of adults in the Sodom and Gomorrah community who were heads of their respective dwellings or households.

\section{Study size and sampling technique}

This was a cross-sectional study. We conceptualised that access to health care in the slum was low and influenced by factors such as availability of health facilities, pattern of health facility use, based in part on knowledge of common illnesses, and on acquisition of health insurance to facilitate use of available health services. Based on this, we selected a total of 465 adults in the community who were heads of their respective dwellings or households. This sample size was deemed sufficient to estimate with $95 \%$ confidence that the proportion of Sodom and Gomorrah dwellers who used a healthcare facility in the last 1 year prior to this survey will not differ from $55 \%$ (the proportion of rural populations in Ghana who consult medical personnel $)^{21}$ by 5 percentage points and accounting for $10 \%$ nonresponse. For convenience and with the aim of covering all parts of the slum, the slum was divided into four areas and in each of these areas, the first household was selected and entered and subsequently every third household were entered till the required sample size was achieved.

\section{Data collection and analysis}

A structured questionnaire with close-ended questions on respondent demographics, use of health facility in the last 1 year, membership of National Health Insurance Scheme (NHIS) and knowledge of causes, signs and symptoms, treatment and prevention of common illnesses in the community was used for data collection. Other data collected on potential barriers to the access and use of healthcare facilities included attitude of healthcare providers, distance to nearest health facility and access to transportation. The questionnaire was independently reviewed and edited by the investigators to ensure quality control and appropriateness for study. The questionnaire was pretested in Makola in the central business district of Accra amongst 50 head porters and truck pushers at the close of day when they were readily available. Pretesting of the questionnaire was done in this group because the investigators perceived that they are similar to the slum residents in demographic characteristics and hassled life styles. Pretesting of the questionnaire did not reveal any need for changes.

A research assistant and her team were trained on the administration of the questionnaire to ensure uniformity and consistency in their approach. The questionnaire was administered individually to participants by a team led by the research assistant moving from dwelling to dwelling within the slum over a 2-week period in December 2011.

Respondents were approached by the research assistant and her team who explained in detail the purpose of the study and solicited participation. Data were entered in Microsoft Office Excel, 2007. A composite indicator for health knowledge based on knowledge of causes, signs and symptoms, and prevention of malaria and cholera and common illnesses mentioned was constructed. Questions assessing knowledge were grouped under six blocks, which are causes of malaria, signs and symptoms of malaria, prevention of malaria, signs and symptoms of cholera, prevention of cholera and knowledge of other illnesses in the slum. Respondents' knowledge was graded as good if they provided at least one correct response for each block. Respondents' knowledge was graded as fair if they provided at least one correct response for only four or five blocks. Respondents' knowledge was graded as poor if they provided at least one correct response for only three or less blocks. Stata $12.1^{22}$ was used for data processing and analysis. Chi-squared test was used to assess statistical differences between independent categorical variables in the levels of use of formal health care.

Risk ratio (RR) estimates and their confidence intervals were estimated by using the modified Poisson regression with a robust error variance. Adjusting the RR for other predictors or potential confounders was done by adding them to the model statement. A $p$-value of $\leq 0.05$ is considered statistically significant. 


\section{Ethics statement}

Ethical approval for this study was granted by the Committee on Human Research, Publications and Ethics, Kwame Nkrumah University of Science and Technology, School of Medical Sciences, Kumasi, Ghana. Written informed consent was sought from all participants and consent obtained before questionnaires were administered. Illiterate participants thumb printed and/or gave verbal consent after they had been provided with adequate information about the study and had all their concerns and/or questions answered.

\section{Results}

We sampled a total of 465 slum dwellers. Two were excluded from the analysis because of nonresponses. The Sodom and Gomorrah community has no hospitals or clinics. The residents said they mostly accessed health care from two drug stores in the slum and from herbalists. A few attended the Cathedral Clinic nearby in the past and only one respondent had ever attended the $\mathrm{KBTH}$, which is a tertiary health facility in the city of Accra. Some demographic characteristics of the participants are presented in Table 1. The majority of respondents were male residents (64.4\%). The median age of respondents was 24 years and ranged

TABLE 1: Some characteristics of residents of Sodom and Gomorrah.

\begin{tabular}{|c|c|c|}
\hline Characteristics & $n$ & $\%$ \\
\hline \multicolumn{3}{|l|}{ Sex } \\
\hline Male & 298 & 64.4 \\
\hline Female & 165 & 35.6 \\
\hline \multicolumn{3}{|l|}{ Age } \\
\hline $18-21$ & 126 & 30.66 \\
\hline $22-25$ & 144 & 35.04 \\
\hline 26 and above & 141 & 34.31 \\
\hline Mean (SD) & 25.6 & (7.5) \\
\hline Median (interquartile range) & 24 & (7) \\
\hline \multicolumn{3}{|l|}{ Ethnic origin } \\
\hline Southern & 164 & 35.9 \\
\hline Northern & 261 & 57.1 \\
\hline Foreign & 32 & 7.0 \\
\hline \multicolumn{3}{|l|}{ Ever visited a health facility } \\
\hline During last year & 72 & 15.9 \\
\hline More than a year ago & 58 & 12.8 \\
\hline Never & 322 & 71.2 \\
\hline \multicolumn{3}{|l|}{ Use of health facility } \\
\hline Yes & 136 & 29.4 \\
\hline No & 327 & 70.6 \\
\hline \multicolumn{3}{|l|}{ NHIS membership } \\
\hline Yes & 90 & 19.4 \\
\hline No & 373 & 80.6 \\
\hline \multicolumn{3}{|l|}{ Meeting health needs } \\
\hline Hospital & 149 & 33.1 \\
\hline Chemical shop & 275 & 61.1 \\
\hline Herbalist & 11 & 2.4 \\
\hline Self-medication & 15 & 3.3 \\
\hline \multicolumn{3}{|c|}{ Transportation to health facility } \\
\hline No problem & 338 & 74.1 \\
\hline A problem & 118 & 25.9 \\
\hline \multicolumn{3}{|l|}{ Distance to health facility } \\
\hline No problem & 333 & 73.2 \\
\hline A problem & 122 & 26.8 \\
\hline
\end{tabular}

NHIS, National Health Insurance Scheme; SD, standard deviation. from 18 to 59 years. The vast majority of respondents (70.5\%) were engaged in nonformal employment, $15.9 \%$ had formal employment and the rest $(13.5 \%)$ were unemployed. Around $60 \%$ of the respondents had had at least a primary-level of education. Majority of the residents (71.2\%) had never visited a health facility anytime in the past. The few (28.8\%) who claimed they did could not recollect their last visit but admitted doing so sporadically in the last 1 or more years ago. When specifically asked, about $29 \%$ of them said they had accessed a formal healthcare unit (hospital, clinic or health centre) in the past 1 year. To meet their health needs, $61.1 \%$ of the residents relied on drug stores, self-medication $(3.3 \%)$ or consulted the herbalist $(2.4 \%)$.

Majority of them $(80.6 \%)$ were not registered members of the NHIS at the time of the survey. They cited lack of money

TABLE 2: Assessment of residents' knowledge on common illnesses.

\begin{tabular}{|c|c|c|}
\hline Characteristics & $n$ & $\%$ \\
\hline \multicolumn{3}{|l|}{ Prevalent illnesses } \\
\hline Malaria & 153 & 34.5 \\
\hline Diarrhoea & 86 & 19.4 \\
\hline Respiratory tract infections & 47 & 10.6 \\
\hline HIV & 14 & 3.2 \\
\hline Mental illness & 53 & 12.0 \\
\hline Other & 90 & 20.3 \\
\hline \multicolumn{3}{|l|}{ Causes of malaria } \\
\hline Mosquito bites & 304 & 67.7 \\
\hline Choked gutters & 27 & 6.0 \\
\hline Rubbish damps & 23 & 5.1 \\
\hline Open gutters & 8 & 1.8 \\
\hline Stagnant waters & 6 & 1.3 \\
\hline Others & 81 & 18.0 \\
\hline \multicolumn{3}{|l|}{ Malaria prevention } \\
\hline Clean environment & 176 & 40.7 \\
\hline Insecticide treated net use & 126 & 29.2 \\
\hline Screen entrances & 15 & 3.5 \\
\hline Use insecticides & 71 & 16.4 \\
\hline Others & 44 & 10.2 \\
\hline \multicolumn{3}{|l|}{ Malaria symptoms } \\
\hline Fever & 149 & 33.1 \\
\hline Headache & 52 & 11.6 \\
\hline Chills & 62 & 13.8 \\
\hline Vomiting & 35 & 7.8 \\
\hline Weakness & 66 & 14.7 \\
\hline Loss of appetite & 16 & 3.6 \\
\hline Others & 70 & 15.6 \\
\hline \multicolumn{3}{|l|}{ Symptoms of cholera } \\
\hline Watery stools & 293 & 64.8 \\
\hline Vomiting & 55 & 12.2 \\
\hline Weakness & 30 & 6.6 \\
\hline Loss of appetite & 6 & 1.3 \\
\hline Others & 68 & 15.0 \\
\hline \multicolumn{3}{|l|}{ Cholera prevention } \\
\hline Good hygiene & 251 & 63.5 \\
\hline Eat clean food & 72 & 18.2 \\
\hline Use clean water & 4 & 1.0 \\
\hline Clean hands & 57 & 14.4 \\
\hline Hygienic food handling & 11 & 2.8 \\
\hline \multicolumn{3}{|l|}{ Overall knowledge score } \\
\hline Poor & 55 & 11.88 \\
\hline Fair & 187 & 40.39 \\
\hline Good & 221 & 47.73 \\
\hline
\end{tabular}


$(45.5 \%)$ for the initial registration as the main reason for not having a national health insurance membership. Other reasons included inconvenience $(13.4 \%)$, no need for it $(9.1 \%)$ and other unexplained reasons $(14.7 \%)$. The respondents were predominantly from the northern parts of Ghana, relative to the south. A few of them were from the West African subregion.

According to the residents, malaria and diarrhoeal diseases were the most prevalent illnesses in the slum because of the prevailing poor sanitation conditions. They also mentioned mental illness, HIV and convulsion in the young, though these were less frequent. Using malaria and cholera, we gauged residents' health awareness by asking about the causes, symptoms and signs, and methods of prevention of the two diseases. Majority of the respondents $(47.7 \%)$ had good knowledge about the causes, symptoms and signs of these illnesses and measures to prevent their occurrence (Table 2).

Factors associated with the use of formal healthcare facilities amongst the slum dwellers are presented in Tables 3 and 4 . Residents aged 26 years or more and those having primary education (6 years of basic education) or higher were significantly more likely to use a formal healthcare facility. However, residents with poor knowledge of causes, signs and symptoms, and prevention of common illnesses in the community and those without jobs or regular incomes and those without NHIS membership were significantly less

TABLE 3: Factors associated with utilisation of health care by residents of Sodom and Gomorrah.

\begin{tabular}{|c|c|c|c|c|c|c|c|}
\hline \multirow[t]{3}{*}{ Associated factors } & \multicolumn{6}{|c|}{ Used healthcare facility } & \multirow[t]{3}{*}{$p$-value } \\
\hline & \multicolumn{2}{|c|}{ No } & \multicolumn{2}{|c|}{ Yes } & \multicolumn{2}{|c|}{ Total } & \\
\hline & $n$ & $\%$ & $n$ & $\%$ & $n$ & $\%$ & \\
\hline \multicolumn{8}{|l|}{ Sex } \\
\hline Male & 204 & 62.39 & 94 & 69.12 & 298 & 64.36 & 0.168 \\
\hline Female & 123 & 37.61 & 42 & 30.88 & 165 & 35.64 & \\
\hline \multicolumn{8}{|l|}{ Age category } \\
\hline $22-25$ & 108 & 37.5 & 36 & 29.27 & 144 & 35.04 & \\
\hline 26 and above & 86 & 29.86 & 55 & 44.72 & 141 & 34.31 & \\
\hline \multicolumn{8}{|l|}{ Marital status } \\
\hline Married & 117 & 36.34 & 55 & 41.67 & 172 & 37.89 & 0.288 \\
\hline Not married & 205 & 63.66 & 77 & 58.33 & 282 & 62.11 & \\
\hline \multicolumn{8}{|l|}{ Education } \\
\hline No education & 146 & 45.48 & 35 & 26.52 & 181 & 39.96 & $<0.001$ \\
\hline Secondary education & 54 & 16.82 & 36 & 27.27 & 90 & 19.87 & \\
\hline \multicolumn{8}{|l|}{ Ethnic origin } \\
\hline Southern & 109 & 33.75 & 55 & 41.04 & 164 & 35.89 & 0.003 \\
\hline Northern & 198 & 61.3 & 63 & 47.01 & 261 & 57.11 & \\
\hline Foreign & 16 & 4.95 & 16 & 11.94 & 32 & 7 & \\
\hline \multicolumn{8}{|l|}{ Occupation } \\
\hline Earn regular income & 42 & 12.96 & 31 & 23.13 & 73 & 15.94 & 0.007 \\
\hline No regular job/income & 282 & 87.04 & 103 & 76.87 & 385 & 84.06 & \\
\hline \multicolumn{8}{|l|}{ NHIS membership } \\
\hline Yes & 48 & 14.68 & 42 & 30.88 & 90 & 19.44 & $<0.001$ \\
\hline No & 279 & 85.32 & 94 & 69.12 & 373 & 80.56 & \\
\hline \multicolumn{8}{|l|}{ Knowledge of symptoms } \\
\hline Some knowledge & 46 & 14.07 & 30 & 22.06 & 76 & 16.41 & 0.034 \\
\hline No knowledge & 281 & 85.93 & 106 & 77.94 & 387 & 83.59 & \\
\hline Fair & 129 & 39.45 & 58 & 42.65 & 187 & 40.39 & \\
\hline Good & 168 & 51.38 & 53 & 38.97 & 221 & 47.73 & \\
\hline \multicolumn{8}{|l|}{ Has chronic illness } \\
\hline No & 303 & 94.39 & 123 & 90.44 & 426 & 93.22 & 0.125 \\
\hline Yes & 18 & 5.61 & 13 & 9.56 & 31 & 6.78 & \\
\hline \multicolumn{8}{|l|}{ Transportation to facility } \\
\hline Not a problem & 254 & 79.38 & 84 & 61.76 & 338 & 74.12 & $<0.001$ \\
\hline A problem & 66 & 20.63 & 52 & 38.24 & 118 & 25.88 & \\
\hline \multicolumn{8}{|l|}{ Distance to facility } \\
\hline Not a problem & 241 & 75.31 & 92 & 68.15 & 333 & 73.19 & 0.115 \\
\hline A problem & 79 & 24.69 & 43 & 31.85 & 122 & 26.81 & \\
\hline \multicolumn{8}{|l|}{ Staff attitude } \\
\hline Not a problem & 177 & 55.14 & 88 & 65.19 & 265 & 58.11 & 0.047 \\
\hline A problem & 144 & 44.86 & 47 & 34.81 & 191 & 41.89 & \\
\hline
\end{tabular}

NHIS, National Health Insurance Scheme. 
TABLE 4: Estimates of relative risk of predictors of utilisation of health care by residents of Sodom and Gomorrah.

\begin{tabular}{|c|c|c|c|c|c|c|}
\hline Predictors of healthcare use & Risk ratio & 95\% Confidence interval & $p$-value & IRR & $95 \%$ Confidence interval & $p$-value \\
\hline \multicolumn{7}{|l|}{ Sex } \\
\hline Male & Reference & & & Reference & & \\
\hline Female & 0.81 & $0.59-1.10$ & 0.176 & 1.14 & $0.82-1.57$ & 0.434 \\
\hline \multicolumn{7}{|l|}{ Age category } \\
\hline $18-$ & Reference & & & Reference & & \\
\hline $22-$ & 0.98 & $0.65-1.48$ & 0.94 & 1.08 & $0.69-1.66$ & 0.732 \\
\hline 26- & 1.54 & $1.06-2.21$ & 0.021 & 1.51 & $0.99-2.28$ & 0.053 \\
\hline \multicolumn{7}{|l|}{ Marital Status } \\
\hline Married & Reference & & & Reference & & \\
\hline Not married & 0.85 & $0.63-1.14$ & 0.285 & 1.34 & $0.96-1.87$ & 0.082 \\
\hline \multicolumn{7}{|l|}{ Education } \\
\hline No education & Reference & & & Reference & & \\
\hline Primary education & 1.73 & $1.20-2.48$ & 0.003 & 1.57 & $1.06-2.30$ & 0.023 \\
\hline Secondary education & 2.07 & $1.39-3.05$ & $<0.001$ & 1.72 & $1.11-2.66$ & 0.014 \\
\hline \multicolumn{7}{|l|}{ Ethnic origin } \\
\hline Southern & Reference & & & Reference & & \\
\hline Northern & 0.72 & $0.53-0.97$ & 0.034 & 0.98 & $0.71-1.34$ & 0.912 \\
\hline Foreign & 1.49 & $0.99-2.24$ & 0.055 & 1.18 & $0.69-2.01$ & 0.541 \\
\hline \multicolumn{7}{|l|}{ Occupation } \\
\hline Earn regular income & Reference & & & Reference & & \\
\hline No regular job/income & 0.63 & $0.46-0.86$ & 0.004 & 0.70 & $0.50-0.96$ & 0.031 \\
\hline \multicolumn{7}{|l|}{ NHIS membership } \\
\hline Yes & Reference & & & Reference & & \\
\hline No & 0.54 & $0.40-0.71$ & $<0.001$ & 0.55 & $0.39-0.75$ & $<0.001$ \\
\hline \multicolumn{7}{|l|}{ Knowledge of symptoms } \\
\hline Some knowledge & Reference & & & Reference & & \\
\hline No knowledge & 0.69 & $0.50-0.95$ & 0.026 & 0.61 & $0.43-0.85$ & 0.004 \\
\hline \multicolumn{7}{|l|}{ Overall knowledge score } \\
\hline Poor & Reference & & & Reference & & \\
\hline Fair & 0.68 & $0.47-0.97$ & 0.038 & 0.64 & $0.42-0.96$ & 0.033 \\
\hline Good & 0.53 & $0.36-0.76$ & 0.001 & 0.44 & $0.28-0.66$ & $<0.001$ \\
\hline \multicolumn{7}{|l|}{ Has chronic illness } \\
\hline No & Reference & & & Reference & & \\
\hline Yes & 1.45 & $0.93-2.25$ & 0.097 & 1.45 & $0.86-2.44$ & 0.158 \\
\hline \multicolumn{7}{|l|}{ Transportation to facility } \\
\hline Not a problem & Reference & & & Reference & & \\
\hline A problem & 1.77 & $1.34-2.33$ & $<0.001$ & 1.62 & $1.17-2.23$ & 0.003 \\
\hline \multicolumn{7}{|l|}{ Distance to facility } \\
\hline Not a problem & Reference & & & Reference & & \\
\hline A problem & 1.28 & $0.94-1.71$ & 0.108 & 1.01 & $0.71-1.43$ & 0.943 \\
\hline \multicolumn{7}{|l|}{ Staff attitude } \\
\hline Not a problem & Reference & & & Reference & & \\
\hline A problem & 0.74 & $0.54-1.00$ & 0.051 & 0.77 & $0.55-1.07$ & 0.122 \\
\hline
\end{tabular}

NHIS, National Health Insurance Scheme.

likely to use a formal healthcare facility. Ethnic origin and gender seemed not to have a significant effect on the use of formal healthcare facilities. Adjusting for the estimated RRs by including all these predictors in the model showed that the level of education, membership of NHIS, overall knowledge of common illnesses in the community and income level are the main factors that determined whether a resident used a formal health. Neither distance (73.2\%) nor transportation to health facility was a problem $(74.1 \%)$ hindering their use of formal health care by residents.

\section{Discussion}

In this study, we assessed utilisation of formal healthcare services by residents of Sodom and Gomorrah as a measure of access to and use of health care. We found that the majority of those sampled were youthful but unskilled, often jobless, and paid less attention to their health and general welfare. Majority of respondents had at least a primary-level education and a good overall knowledge about prevalent illnesses amongst residents of the slum. Just about 2 out of 10 respondents had an NHIS membership. A resident with NHIS membership was more than twice as likely to use a formal healthcare facility. Sodom and Gomorrah is centrally located in Accra and just about $300 \mathrm{~m}$ from the KBTH and even closer to other smaller health facilities. Indeed, the respondents indicated that neither distance nor access to transportation hindered them from using a health facility. Despite the central location of the slum and its proximity to healthcare facilities, it was interesting to note that less than 3 out of 10 used formal health care when they had need for it. They chose instead to seek from other sources. 
However, Agarwal and colleagues ${ }^{16}$ suggest that this is not always the case. They argued that if health authorities appropriately respond, proximity to formal healthcare facilities leads to improved health awareness, which positively influences healthcare use and health-seeking behaviour. $^{16}$

The main health problems prevalent in this slum were malaria and diarrhoeal diseases. This is not surprising as the community has no pipe-borne water or good sanitary facilities. Sanitation is generally poor. There are no wellconstructed gutters or drainage systems to allow easy flow of water. The few open gutters are choked with debris, resulting in dirty stagnant ponds and flooding during the rainy season. Houses are overcrowded and all-purpose. This is typical of slums as was observed in other studies conducted in slums. ${ }^{5,6,8,23}$ Living in slums under deprived conditions is a major cause of ill-health and slum dwellers suffer disproportionately from ill-health throughout their life course. ${ }^{3,5,24,25,26,27}$

It was observed that residents of Sodom and Gomorrah live in poor shacks primarily built or held together with old roofing sheets, plywood and/or cardboard papers. Children appeared neglected and malnourished, whilst adults loiter around smoking marijuana, sometimes with young children looking on. These conditions characterise Sodom and Gomorrah as a slum as defined operationally by the UN. ${ }^{28}$ However, it is difficult to explain why residents 'feel' at home under such profound deprivation prevailing in Sodom and Gomorrah. It is also needless to argue the circumstances leading to the creation of this slum as the demographic and socio-economic indicators are similar to those found in slums worldwide. ${ }^{1,2}$ However, the existence of such slums may be an expression of social exclusion. Slums appear to have intergenerational negative effects because children born in the slum have a slim chance of breaking through the poverty cycle. The significance of this study is its novelty and the information gleaned about the lives of slum dwellers within the city of Accra thus providing clues for effective interventions to improve the quality of their lives.

These results suggest that proximity of Sodom and Gomorrah to a tertiary health facility and many others in the centre of Accra did not necessarily encourage their patronage amongst the residents. However, just as it is the case for most Ghanaians, health-seeking behaviour is influenced by cultural and religious beliefs and practices. ${ }^{29,30,31,32}$ This study, however, did not include a qualitative component to help understand the complex social phenomenon of the health-seeking behaviours of the slum residents. Inclusion of such data could have informed findings and targeted interventions. Future studies need to include these psycho-social measures for greater understanding of the health-seeking behaviours of slum dwellers.

\section{Conclusion}

Increasing urbanisation is a major factor in the creation and continued existence of the Sodom and Gomorrah slum. The slum reveals a 'theatre of social exclusion' where prevailing poor economic, educational and sociocultural conditions conspire as if to perpetuate each other's reign. Conditions of profound environmental hazards, overcrowding and poor-quality housing and lack of health care or other essential services in Sodom and Gomorrah pose grave threats to the health of the inhabitants and probably to the rest of the city of Accra. Interventions requiring significant multisectoral effort and resource mobilisation championed by the Ministry of Local Government and Rural Development are needed to attempt a resolution of this crisis.

\section{Acknowledgements}

We thank all the participants who gave their time to participate in the study and the entire field team that worked so hard in collecting and processing the data.

\section{Competing interests}

The authors declare that they have no financial or personal relationship(s) that may have inappropriately influenced them in writing this article.

\section{Authors' contributions}

H.T. (Kwame Nkrumah University of Science and Technology) and F.E.O.A. (Kwame Nkrumah University of Science and Technology) devised the study design and objectives. H.T., M.A.T. (Military Hospital) and F.E.O.A. contributed to data collection, analysis and interpretation. F.E.O.A. wrote the first draft of the manuscript. All authors read, commented on and approved the final manuscript.

\section{References}

1. Unger A, Riley LW. Slum health: From understanding to action. PLoS Med. 2007;4(10):e295.

2. UN-HABITAT. The challenge of the slums: Global report on human settlements. Nairobi: United Nations; 2003

3. Sheuya SA. Improving the health and lives of people living in slums. Ann N Y Acad Sci. 2008;1136:298-306.

4. Wagstaff A. Poverty and health sector inequalities. Bull World Health Organ. 2002;80(2):97-105.

5. Szwarcwald $\mathrm{CL}$, Andrade $\mathrm{CL}$, Bastos FI. Income inequality, residential poverty clustering and infant mortality: A study in Rio de Janeiro, Brazil. Soc Sci Med. 2002;55(12):2083-2092.

6. Szwarcwald CL, Bastos FI, Barcellos C, Pina MF, Esteves MA. Health conditions and residential concentration of poverty: A study in Rio de Janeiro, Brazil. J Epidemiol Community Health. 2000;54(7):530-536.

7. Agyei-Mensah S, de-Graft Aikins A. Epidemiological transition and the double burden of disease in Accra, Ghana. J Urban Health. 2010;87(5):879-897.

8. Sverdlik A. III-health and poverty: A literature review on health in informal settlements. Environ Urban. 2011;23(1):123-155

9. WHO. A billion voices: Listening and responding to the health needs of slum dwellers and informal settlers in New Urban settings. Japan: WHO Kobe Center, Chuo-ku; 2005.

10. Zulu EM, Beguy D, Ezeh AC, Bocquier P, Madise NJ, Cleland J, et al. Overview of migration, poverty and health dynamics in Nairobi City's slum settlements. J Urban Health. 2011;88 S185-199. 
11. Skordis-Worrall J, Pace N, Bapat U, Das S, More NS, Joshi W, et al. Maternal and neonatal health expenditure in Mumbai slums (India): A cross sectional study. BMC Public Health. 2011;11:150.

12. Matthews Z, Channon A, Neal S, Osrin D, Madise N, Stones W. Examining the 'urban advantage' in maternal health care in developing countries. PLoS Med. 2010;7(9):e1000327.

13. Halder AK, Gurley ES, Naheed A, Saha SK, Brooks WA, El Arifeen S, et al. Causes of early childhood deaths in urban Dhaka, Bangladesh. PLoS One. 2009; 4(12):e8145.

14. Bulatao RA, Ross JA. Which health services reduce maternal mortality? Evidence from ratings of maternal health services. Trop Med Int Health. 2003;8(8):710-721.

15. Matthews Z, Brookes M, Stones RW, Hossain MB. Village in the city: Autonomy and maternal health-seeking among slum populations of Mumbai. In: Kishor S, editor A focus on gender: Collected papers on ender using DHS data. Calverton, MD: ORC Macro, 2005; p. 69-92.

16. Agarwal S, Taneja S. All slums are not equal: Child health conditions among the urban poor. Indian Pediatr. 2005;42(3):233-244.

17. Ashton JR. Back to back housing, courts and privies: The slums of the 19th century England. J Epidemiol Community Health. 2006;60:654.

18. Michielsen J, Denny J, Nilangi S, Herman M. Improving access to quality care for female slum dwellers in urban Maharashtra, India: Researching the need for transformative social protection in health. Soc Theor Health. 2011;9(4):367-392.

19. United Nations. The millennium development goals report. New York: United Nations; 2007.

20. Cassels S, Jenness SM, Biney AAE, Ampofo WK, Dodoo FN-A. Migration, sexual networks, and HIV in Agbogbloshie, Ghana. Demogr Res. 2014;31:861-888.

21. Heyen-Perschon J. Report on current situation in the health sector of Ghana and possible roles for appropriate transport technology and transport related communication interventions; Institute for Transportation and Development Policy, ITDP; Wohltorf, Germany; 2005.

22. StataCorp. Stata Statistical Software: Release 12.1. College Station, TX: StataCorp LP; 2011.

23. Stephenson R, Matthews Z, McDonald JW. The impact of rural-urban migration on under-two mortality in India. J Biosoc Sci. 2003;35(1):15-31.

24. Fotso JC. Child health inequities in developing countries: Differences across urban and rural areas. Int J Equity Health. 2006;5:9.

25. Fotso JC. Urban-rural differentials in child malnutrition: Trends and socioeconomic correlates in sub-Saharan Africa. Health Place. 2007;13(1):205-23.

26. Riley LW, Ko Al, Unger A, Reis MG. Slum health: Diseases of neglected populations. BMC Int Health Hum Rights. 2007;7:2.

27. Sclar ED, Garau P, Carolini G. The 21st century health challenge of slums and cities. Lancet. 2005;365(9462):901-903.

28. UN-HABITAT. Defining slums: Towards an operational definition for measuring slums. Background Paper 2, Expert group meeting on slum indicators, October. Nairobi: United Nations; 2002

29. Ae-Ngibise K, Cooper S, Adiibokah E, Akpalu B, Lund C, Doku V, et al. 'Whether you like it or not people with mental problems are going to go to them': A qualitative exploration into the widespread use of traditional and faith healers in the provision of mental health care in Ghana. Int Rev Psychiatry. 2010;22(6):558-567.

30. Danquah SA. The practice of behaviour therapy in West Africa: the case of Ghana. J Behav Ther Exp Psychiatry. 1982;13(1):5-13.

31. Jahoda G. On the nature of difficulties in spatial-perceptual tasks: Ethnic and sex differences. Br J Psychol. 1979;70(3):351-363.

32. Sarpong P. Ghana in retrospect: Some aspects of the Ghanaian culture. African Books Collective Ltd; Ghana; 1991. 